\title{
Field-scale bio-cementation tests to improve sands
}

1 Michael G. Gomez MSc

Graduate Student, Department of Civil and Environmental

Engineering, University of California: Davis, Davis, CA, USA

2 Brian C. Martinez MSc, PhD

Senior Staff Engineer, Geosyntec Consultants, Oakland, CA, USA

3 Jason T. DeJong MSc, PhD

Professor, Department of Civil and Environmental Engineering, University of California: Davis, Davis, CA, USA
4 Chris E. Hunt MSc, PhD, PE, GE

Associate, Geosyntec Consultants, Oakland, CA, USA

5 Len A. deVlaming MSc

Senior Process Engineer, Geosyntec Consultants, Guelph, ON Canada

6 David W. Major MSc, PhD

Principal, Geosyntec Consultants, Guelph, ON, Canada

7 Sandra M. Dworatzek MSC

Senior Manager, SiREM Laboratories, Guelph, ON, Canada
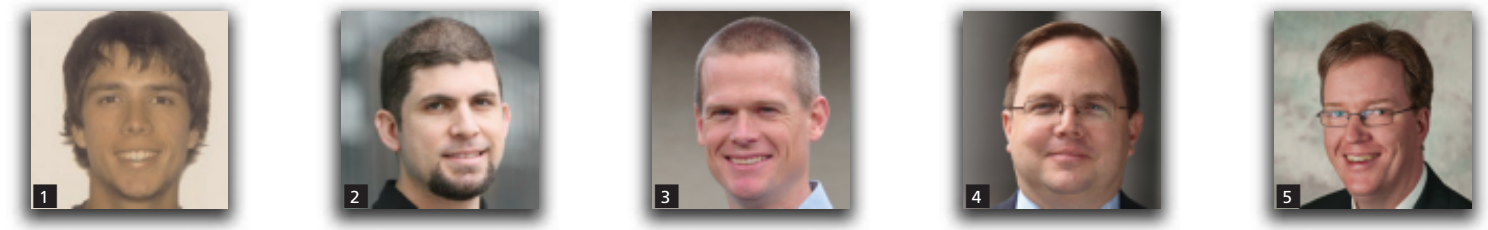
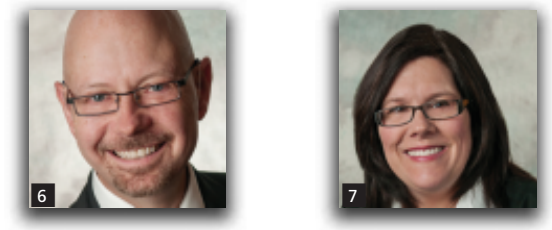

Microbially induced calcite precipitation (MICP) is a bio-mediated cementation process that improves the geotechnical properties of soils through the precipitation of calcite at soil particle contacts. This study presents a field-scale, surficial application of MICP to improve the erosion resistance of loose sand deposits and provide surface stabilisation for dust control and future re-vegetation. Three test plots were treated with a bacterial culture and nutrient solutions at varying concentrations, and a fourth test plot served as a control. Improvement was assessed to a depth of $40 \mathrm{~cm}$ using dynamic cone penetration (DCP) testing and calcite content measurements. The most improved test plot received the lowest concentrations of urea and calcium chloride and developed a stiff crust measuring $2.5 \mathrm{~cm}$ thick, which exhibited increased resistance to erosion. DCP testing and calcite content measurements indicated improvement to a depth of approximately $28 \mathrm{~cm}$ near the targeted depth of $30 \mathrm{~cm}$. The results suggest that further optimisation of solutions and techniques could render MICP viable for larger-scale applications.

\section{Introduction}

Microbially induced calcite precipitation (MICP) is a biocementation process that can improve the geotechnical properties of granular soils through the precipitation of calcium carbonate (calcite) at soil particle contacts (Stocks-Fisher et al., 1999). The most extensively researched MICP biogeochemical reaction is enabled by Sporoscarcina pasteurii (S. pasteurii), a soil bacterium that harbours a highly active urease enzyme associated with urea hydrolysis (Ferris et al., 1996). In the presence of urea, this urease enzyme can catalyse a hydrolysis reaction that results in the production of ammonia and carbon dioxide gas. The production of hydroxide ions occurs when produced ammonia reacts with water to generate ammonium ions. In addition, carbon dioxide resulting from urea hydrolysis will proceed to dissolve in water, generating carbonic acid. The carbonic acid produced will deprotonate more readily in the basic environment formed by the production of hydroxide ions, to form bicarbonate and carbonate ions. As these carbonate ions become increasingly available, the addition of calcium at sufficient concentrations may supersaturate the aqueous solution with respect to calcite, resulting in precipitation. The precipitation of calcite at soil particle contacts results in improvement of geotechnical properties such as soil matrix stiffness, initial shear stiffness and shear strength (DeJong et al., 2006; Harkes et al., 2008; Whiffin et al., 2007).

Through laboratory experimentation at the bench scale, MICP technology has been demonstrated as an effective method to improve sands (Burbank et al., 2011; Chu et al., 2009, 2012; DeJong et al., 2006; Hamdan et al., 2011; Montoya et al., 2012; Tagliaferri et al., 2011; Weaver et al., 2011; Whiffin et al., 2007). 
As a less intrusive and potentially more environmentally favourable ground improvement method, MICP offers an alternative to traditional soil improvement methods such as cement mixing and jet grouting. Although MICP experimentation has been largely confined to the laboratory, field-scale applications have been demonstrated with success in the Netherlands (van Paassen, 2011), and are currently being implemented at a US Department of Energy site in Rifle, Colorado (Smith et al., 2012). The future of MICP as a practical ground improvement method is dependent on these field-scale applications, which provide essential information about the biogeochemical process at the metre scale.

In this study a field-scale, surficial application of MICP was completed at a mine site location in the province of Saskatchewan, Canada. The objective of this study was to assess the ability of MICP treatments to improve loose sands by increasing erosion resistance, surficial stability and dust abatement, and potentially to enable re-vegetation. The treatment programme targeted improvement to a depth of $30 \mathrm{~cm}$. Treatment solutions were formulated to achieve soil improvement at levels that would meet project goals by considering results from previous smallscale laboratory studies (DeJong et al., 2010; Martinez and DeJong, 2009; Montoya et al., 2012 and others).

Four test plots each measuring $2.4 \mathrm{~m} \times 4.9 \mathrm{~m}$ were established at the project location. Three test plots received both bacterial culture and nutrient amendments (test plots TP2, TP3 and TP4), while a control test plot (TP1) received only water at the same volumes applied to other test plots. Different concentrations of urea and calcium chloride were applied to each test plot to provide insight about cementation efficiency for future upscaling to larger-scale applications. A project site with relatively uniform soil conditions was selected in order to allow for comparisons between test plots. As shown in Figure 1(a), this site consisted of loose, poorly graded sand that originated from the excavation of overburden material at an adjacent mining pit. This sand was continuously eroded by high winds and precipitation and therefore required stabilisation. As depicted in Figure 1(b), test plots were established on these sands to assess the capability of MICP to stabilise this material. In order to mitigate potential bacterial contamination of the control, TP1 was located upwind of other biologically treated plots. Sand berms approximately $25.4 \mathrm{~cm}$ in height were also constructed around the perimeter of each test plot to prevent surrounding erodible sands from being blown onto test plots during the study.

\section{Materials and methods}

\subsection{Treatment solutions}

Treatment solutions were applied to treated test plots in a series of five identical 4-d cycles (cycle day no. 1, 2, 3 and 4), totalling 20 consecutive days of treatment. Table 1 presents the treatment type that was applied to test plots for each cycle day. TP2, TP3 and TP4 each received a single day of bacterial amendment application followed by $3 \mathrm{~d}$ of nutrient amendment applications

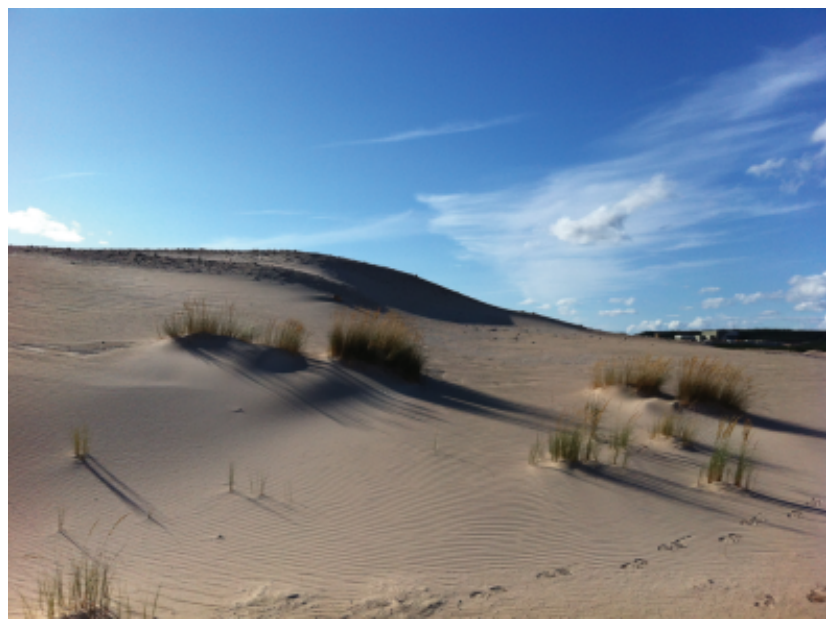

(a)

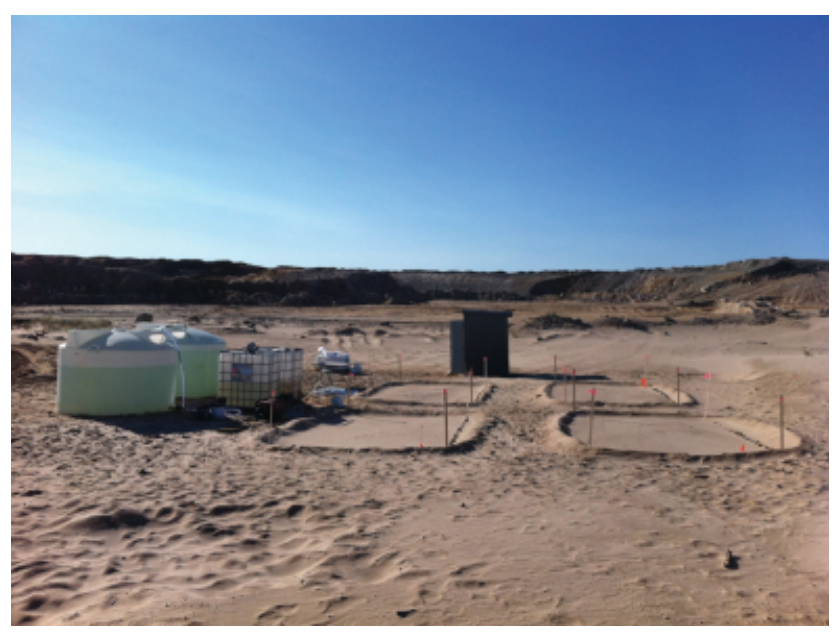

(b)

Figure 1. (a) Overburden sands on-site existed in a very loose state susceptible to erosion by wind and precipitation. (b) Test plots were established within this region of uniform, loose, poorly graded sand for field-scale MICP tests

\begin{tabular}{lll}
\hline Cycle day no. & Treatment type $^{\mathrm{a}}$ & Field monitoring $^{\mathrm{b}}$ \\
\hline 1 & Bacterial & DCP, DS \\
2 & Nutrient & - \\
3 & Nutrient & DCP \\
4 & Nutrient & - \\
\hline
\end{tabular}

a 'Bacterial' indicates cycle days for application of bacteria amendment. 'Nutrient' indicates cycle days for application of nutrient amendment.

$b$ ' $D C P^{\prime}$ indicates days when DCP measurements occurred at three locations on test plots. 'DS' indicates days when discrete samples were collected at similar locations for calcite measurements.

Table 1. Summary of monitoring and treatments 
each cycle. The application of bacteria every fourth day instead of every day was intended to optimise the efficiency of the biogeochemical process. Table 2 presents the composition of the bacterial amendment solutions. Nutrient amendment solutions contained the same calcium chloride and urea concentrations as the bacterial amendment solutions for each respective test plot but were not augmented with $S$. pasteurii at the cell density of $10^{8}$ cells $/ 1$. Bacterial solutions were applied on cycle day no. 1 , and the nutrient amendment solutions were applied on cycle days no. 2 to 4 .

Treatment formulations differed in concentrations of urea and calcium chloride between test plots; however the molar ratio of urea to calcium chloride remained at 2:1. TP2 solutions were developed from previous laboratory experiments completed with success (Martinez and DeJong, 2009) and included the highest concentrations of both urea and calcium chloride. TP3 solutions contained one-half of the concentration of urea and calcium chloride as used in the TP2 solutions and TP4 solutions contained one-quarter of the concentration. TP1 received tap water at identical volumes. The treatment volume applied was 378.51 per test plot daily. This treatment volume was estimated as the fluid volume needed to occupy $25 \%$ of the void space after assuming a void ratio of 0.4 and a treatment depth of $30 \mathrm{~cm}$. It was hypothesised that TP2 with the largest concentration of urea and calcium chloride would produce the highest level of cementation and soil improvement, with TP3 and TP4 having correspondingly lower levels of cementation.

\subsection{Bacterial culture inoculant}

Sporoscarcina pasteurii bacterial culture inoculant was stir cultured in a liquid medium at SiREM Laboratories in Guelph, ON to a cell density of $10^{10}$ cells/ 1 from a culture purchased from the American Type Culture Collection (ATCC \#1376). The bacterial culture inoculant constituents are presented in Table 3. The culture was sent to the project location in 41 containers periodically to minimise storage time. The culture containers were stored in large coolers with ice packs until application.

\subsection{Treatment preparation, mixing and application}

Treatment solutions were prepared in two 11351 IBC containers and applied to test plots using a hose and application wand

\begin{tabular}{llcccc}
$\begin{array}{l}\text { Test } \\
\text { plot }\end{array}$ & Type & $\begin{array}{c}\text { S. pasteurii: } \\
\text { cells/la }\end{array}$ & $\begin{array}{c}\text { Nutrient } \\
\text { broth: mg/l }\end{array}$ & $\begin{array}{c}\text { Urea: } \\
\text { g/l }\end{array}$ & $\begin{array}{c}\text { Calcium } \\
\text { chloride: g/l }\end{array}$ \\
\hline 1 & Control & - & 0 & 0 & 0 \\
2 & MICP & $10^{8}$ & $58 \cdot 7$ & 60 & $55 \cdot 5$ \\
3 & MICP & $10^{8}$ & $58 \cdot 7$ & 30 & $27 \cdot 75$ \\
4 & MICP & $10^{8}$ & $58 \cdot 7$ & 15 & $13 \cdot 875$ \\
\hline
\end{tabular}

a Nutrient amendment solutions differed by having no $S$. pasteurii addition (0 cells/l).

Table 2. Bacterial amendment constituents

\begin{tabular}{lc} 
Constituent & Concentration \\
\hline Yeast extract: g/l & 20 \\
Ammonium sulfate: g/l & 10 \\
Trisma acid: g/l & $3 \cdot 4$ \\
Trisma base: g/l & $13 \cdot 1$ \\
S. pasteurii: cells/l & $10^{10}$
\end{tabular}

Table 3. Bacterial culture inoculant constituents

assembly, as shown in a schematic diagram in Figure 2. Two 56781 polyurethane water tanks were used to store water on site. The sprayer and hose assembly were assembled from polyvinyl chloride (PVC) pipe fittings and a fine spray nozzle. Two separate recirculating pumps were used to pump water or solutions as needed from the large storage tanks to the application wand, the large storage tanks to the mixing totes, or the mixing totes to the application wand. To avoid bacterial contamination of the water tanks, one pump and hose assembly was dedicated to clean water and TP1 treatments, and a second was used for treatment solutions.

Treatment volumes of 3791 were applied to each test plot; however, batches of 5681 were prepared to limit distribution pump suction problems and promote consistent application of solutions. Excess treatment solutions were discharged at a designated location away from the test plots. Treatment solutions were mixed until no constituent particulates remained visible and the $\mathrm{pH}$ of each solution remained constant. Solutions were also mixed during the application process to prevent chemical settling and provide consistency in treatment solutions. An initial $\mathrm{pH}$ between 5.5 and $7 \cdot 5$ after the addition of bacteria was targeted for bacterial amendment solutions. For the application of nutrient amendment solutions an initial $\mathrm{pH}$ between 5.5 and 7.0 was targeted. Target $\mathrm{pH}$ values were accomplished by titrating treatment solutions with $1 \mathrm{~mol} / \mathrm{l}$ hydrochloric acid $(\mathrm{HCl})$ while monitoring $\mathrm{pH}$. Solution $\mathrm{pH}$ values were adjusted to allow treatment solutions to be applied to test plots before calcite precipitation occurred.

Treatment solutions were applied uniformly across plot surfaces. An application wand used to apply treatment solutions was calibrated to a flow rate of approximately $191 / \mathrm{min}$. Following an application, test plot surface soils became saturated in appearance and surface ponding typically developed for a short period of time while infiltration occurred. TP1 applications were completed using the same application technique and rate of application as used for other test plots.

\subsection{Monitoring schedule}

Field measurements and sample collection were performed on each test plot to monitor both chemical and geotechnical changes over time. Dynamic cone penetrometer (DCP) measurements were performed to evaluate changes in penetration resistance and 


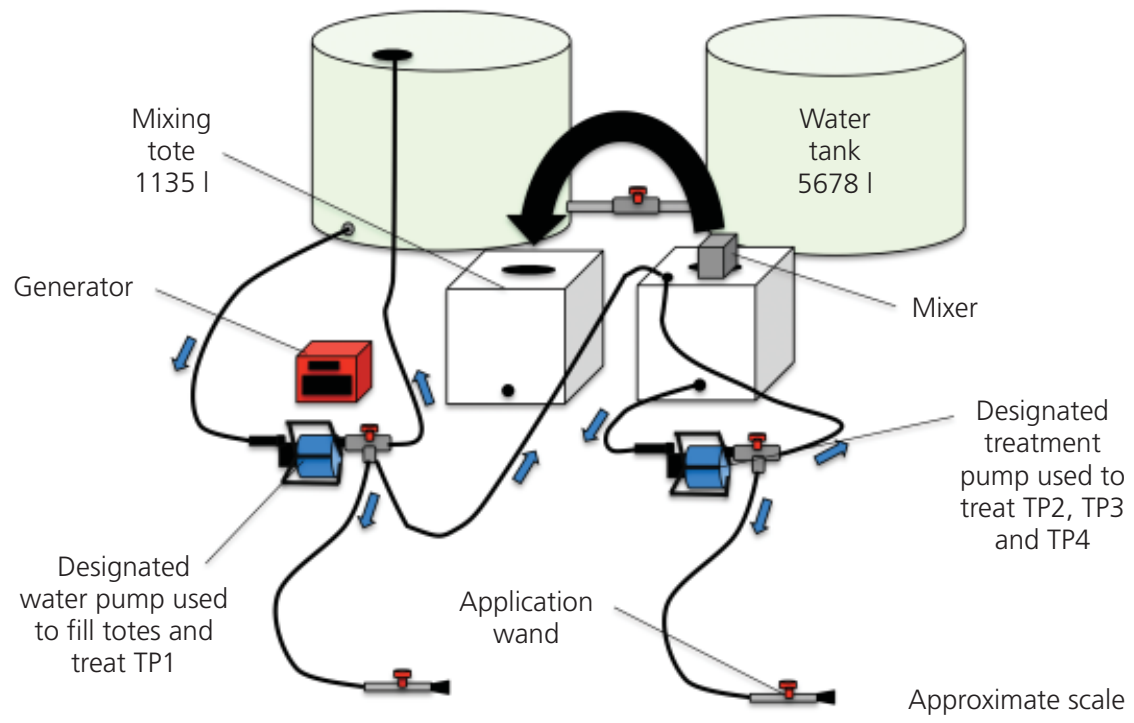

Figure 2. The surficial application system used to apply treatment solutions included using two separate pumps, mixing totes and water tanks

discrete samples were collected to perform calcite content measurements. Figure 3 displays both the DCP measurement (Figure 3(a)) and sampling locations (Figure 3(b)) used throughout the study. Sample locations were randomly selected using a random number generator but constrained to provide a broad spatial distribution across each test plot for a given day. The sampling region consisted of a $1.8 \mathrm{~m} \times 4.3 \mathrm{~m}$ grid, which provided a minimum $30 \mathrm{~cm}$ offset between any sample and the test plot perimeter. Each grid was further subdivided into three $1.8 \mathrm{~m} \times 1.4 \mathrm{~m}$ sections. On each sampling day, sample collection and/or field measurements were performed in each of these three sections. All measurement locations were identical for all four test plots.

Monitoring was completed on specific days of each treatment cycle and was repeated for all five cycles. Table 1 presents the monitoring methods completed on test plots for each cycle day. On the final day of treatment (day 20), five discrete samples were extracted and nine additional DCP measurements were performed on each plot. Five DCP measurements and discrete samples were taken at identical locations on day 20 and distributed evenly across the test plots. An additional nine DCP measurements were taken at similar locations as the day 20 DCP measurements both $44 \mathrm{~d}$ after treatment completion (day 64) and following a winter season $298 \mathrm{~d}$ after treatment completion (day 318). In total, during treatment and subsequent monitoring, 57 DCP measurements were performed and discrete samples were extracted at 20 locations on each of the four test plots.

\subsection{Dynamic cone penetrometer measurements}

Penetration resistance was monitored using a dual-mass DCP from the Salem Tool Company, in accordance with ASTM D6951 (ASTM, 2009). During the first $10 \mathrm{~d}$ of monitoring, blow count measurements were completed using an $8 \mathrm{~kg}$ donut hammer dropped the full $57.4 \mathrm{~cm}$ specified in the standard. The data collected while using the $8 \mathrm{~kg}$ hammer at full drop height did not provide sufficient resolution with depth, as the DCP cone advanced large depths with each blow. In order to resolve small changes in cementation on test plots a lower energy method was needed. For all subsequent monitoring, DCP measurements were completed using a lower energy $4.6 \mathrm{~kg}$ donut hammer at a quarter drop height, $14.4 \mathrm{~cm}$.

A side study was conducted in order to ensure that data from both methods could be normalised by the energy input. DCP measurements were performed using four different energy methods at similar locations. The different energy methods included using an $8 \mathrm{~kg}$ hammer at full $(57.4 \mathrm{~cm})$ drop height $(45 \mathrm{~J})$, a $4.6 \mathrm{~kg}$ hammer at full $(57.4 \mathrm{~cm})$ drop height $(25.9 \mathrm{~J})$, a $4.6 \mathrm{~kg}$ hammer at half $(28.7 \mathrm{~cm})$ drop height $(12.9 \mathrm{~J})$, and a $4.6 \mathrm{~kg}$ hammer at quarter $(14.4 \mathrm{~cm})$ drop height $(6.5 \mathrm{~J})$. When measurements were normalised to the energy input of the $4.6 \mathrm{~kg}$ hammer at quarter stroke method $(6.5 \mathrm{~J})$, measurements agreed with depth for all energy methods. As such, all DCP measurements presented in this study are plotted after energy normalisation to the reference condition of $6.5 \mathrm{~J}$ per hammer blow. It should be noted that DCP measurements collected after day 10 were obtained with the $6.5 \mathrm{~J}$ method and therefore did not require energy normalisation.

DCP penetration resistance measurements were recorded relative to a reference elevation. The top of the ground surface was designated as the zero reference to capture improvement in the upper crust. This reference deviates slightly from ASTM D6951 (ASTM, 2009), which designates the line above the conical section of the cone tip as the zero reference. Free-fall measurements were 

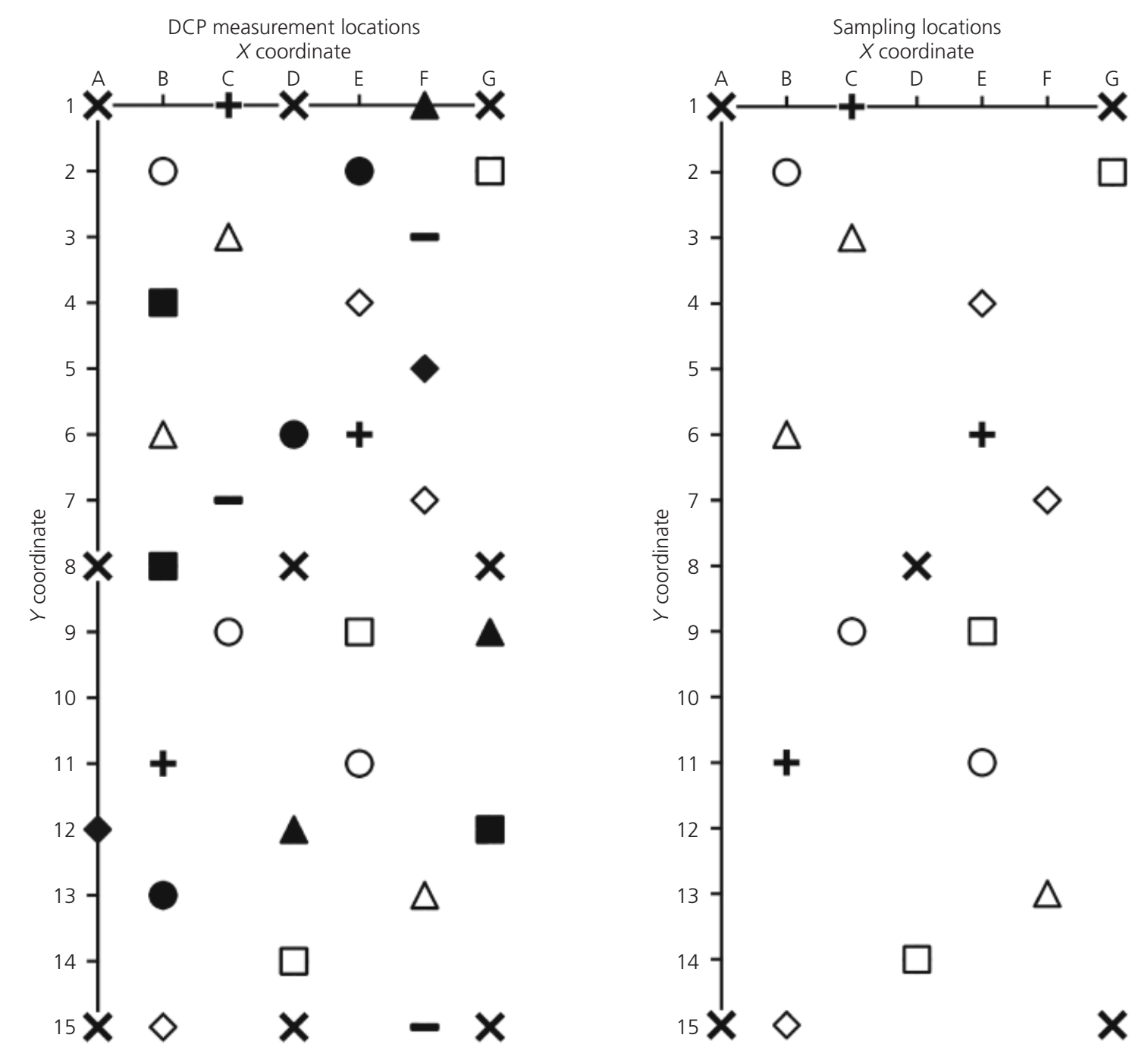
$\diamond$ Day 0
- Day 2
Day 8
A Day 6
Day 12
- Day 18
Day 14
X Days 20 and 64
$\triangle$ Day 4
Day 10
Day 16

(a)

\begin{abstract}
$\diamond$ Day 0
\end{abstract}
$\Delta$ Day 4

Day 8

$\square$ Day 12

+ Day 16

X Day 20

Figure 3. (a) DCP measurement and (b) discrete sampling locations were constrained to provide a broad spatial distribution across each test plot for a given day. These locations were identical for all four test plots

also taken to measure the distance that the DCP cone tip penetrated from self-weight alone. Depth measurements after repeated hammer blows were recorded to develop blow/cm (blow count) profiles with depth. DCP measurements were terminated at a depth of approximately $40 \mathrm{~cm}$, past the target $30 \mathrm{~cm}$ treatment depth. All holes generated by DCP measurements were filled with untreated sand to reduce formation of potential drainage paths during subsequent treatment applications.

\subsection{Discrete sampling and calcite measurements}

Thin-walled steel sampling tubes $24.5 \mathrm{~cm}$ in length and $3.2 \mathrm{~cm}$ in inner diameter were used to obtain discrete samples from all plots 
for calcite measurements. The sampling intervals used during the study separated material from the top $3.8 \mathrm{~cm}$, the next $3.8 \mathrm{~cm}$, $7.6 \mathrm{~cm}$ and bottom $10.2 \mathrm{~cm}$. All samples were stored in sealed plastic bags for later laboratory analysis.

Two calcite chambers were used to monitor changes in calcite content, in accordance with ASTM D4373 (ASTM, 2002). Calcite chamber measurements were performed on collected samples to evaluate changes in calcite content with depth and time. Samples from a given depth interval were dried and mixed thoroughly to obtain a dry representative sample. The chambers utilise a reaction between calcite and $\mathrm{HCl}$, which generates carbon dioxide gas and a corresponding increase in chamber pressure. Previously calibrated laboratory relationships between chamber pressure and calcite mass were used to calculate calcite mass from observed chamber pressure.

\subsection{Water jet impingement erosion test}

A water jet impingement erosion test was developed to assess the ability of cemented soils to mitigate erosion following final treatment. While this test was not based on an accepted standard, it was performed to qualitatively evaluate the erosion resistance of each test plot. During the test, the application spray wand applied water to test plot surfaces from a height of $107 \mathrm{~cm}$ using a flow rate of approximately $22 \cdot 7 \mathrm{l} / \mathrm{min}$. The erosion resistance of each test plot was assessed based upon the amount of erosion that was observed following 1 min of jet impingement. Images of test plot surfaces were taken following these tests.

\section{Results and discussion}

\subsection{Visual observations}

At the conclusion of MICP treatment applications, a sandstonelike crust was observed on all three biologically treated test plots, although at various degrees. In order to determine crust thicknesses, cemented soils were physically removed from plot surfaces until the material became removable without breaking cemented bonds, as shown in Figure 4(a). Crust thicknesses were then measured at four locations on each test plot. The maximum and minimum crust thicknesses are shown in Table 4 . TP4 was shown to have both the largest maximum $(2.54 \mathrm{~cm})$ and minimum $(0.64 \mathrm{~cm})$ crust thicknesses.

Although the presence of cemented crusts on the test plots indicated improvement, it was unclear how these cemented crusts would perform once exposed to high winds and precipitation, which commonly occur at the site. Water jet impingement erosion tests were conducted to assess visually the erosion resistance of test plots. During the test, TP1 (untreated sand) experienced significant surficial erosion almost instantaneously. After 1 min of water application an impression remained where sand had been displaced and loose sand filled the developing void. When TP2 was tested, the existing crustal layer was shown to resist significant erosion; however, some surficial erosion did occur at weaker points on the crust. Following testing on TP3, no significant

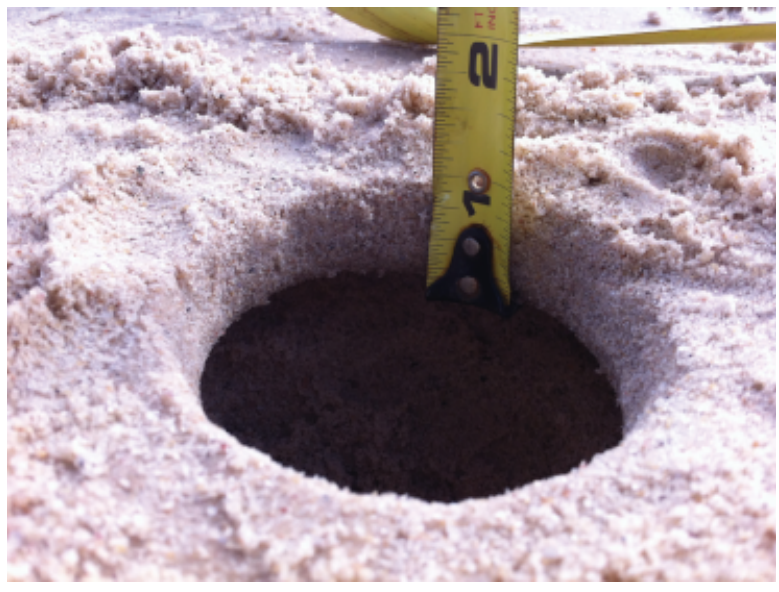

(a)

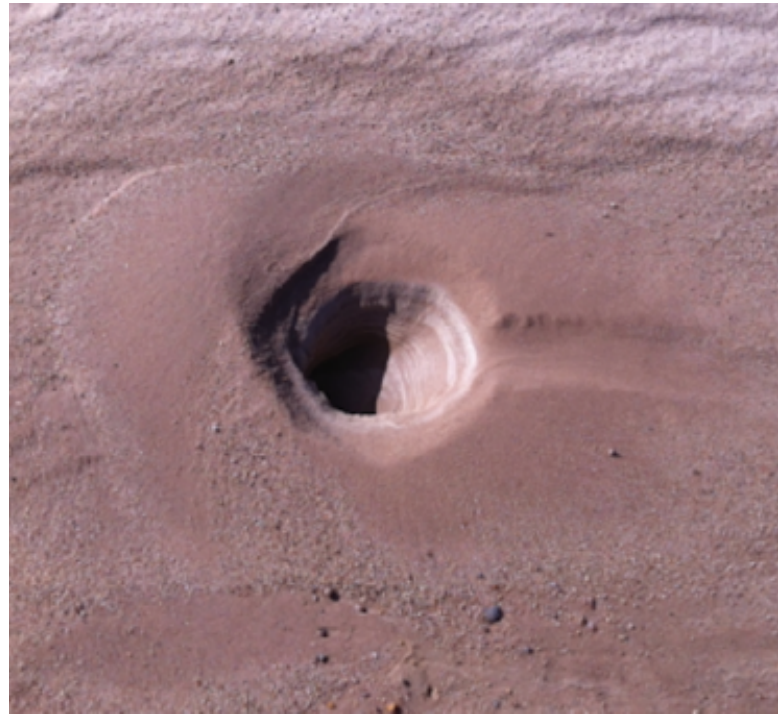

(b)

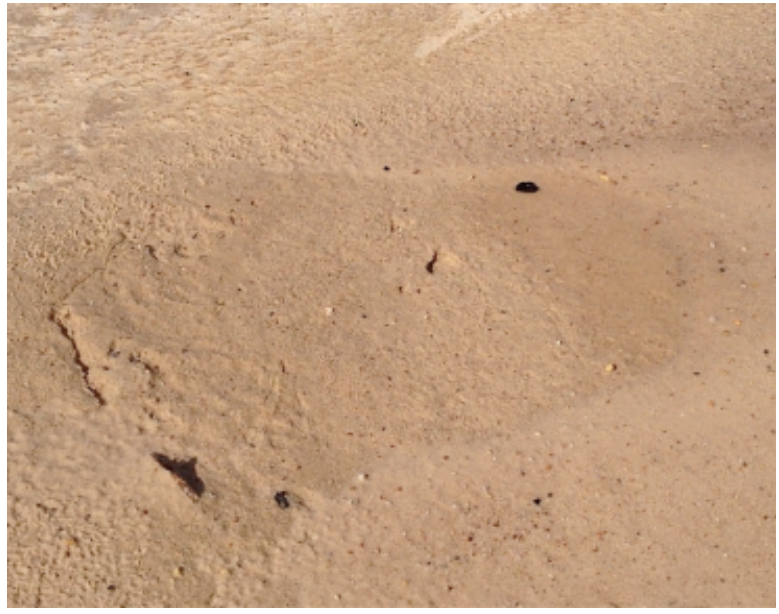

(c)

Figure 4. (a) Thicknesses of cemented crusts were measured by excavating cemented sand material on test plots. After completion of water jetting tests, images were taken of (b) a region of untreated sand and (c) test plot 4 
Test plot Minimum thickness: $\mathrm{cm}$ Maximum thickness: $\mathrm{cm}$

\begin{tabular}{lcc}
\hline 1 & - & - \\
2 & 0 & 0.32 \\
3 & 0.32 & $1 \cdot 27$ \\
4 & 0.64 & $2 \cdot 54$ \\
& \\
&
\end{tabular}

erosion was observed. Lastly when TP4 was tested, no visible erosion of the crust was observed. Figures 4(b) and 4(c) display images of both an untreated soil surface and the TP4 soil surface respectively, following the water jet impingement erosion tests. Although these qualitative results suggest that the greatest improvement occurred on TP4, additional results were needed with respect to penetration resistance and calcite content.

\subsection{Penetration resistance}

To compare improvements between plots it was first necessary to assess spatial variability across the project site. To confirm that similar initial conditions existed across the project site, both $45 \mathrm{~J}$ and $6.5 \mathrm{~J}$ measurements from day zero for all test plots were plotted together (Figure 5). From this result, it was concluded that all test plots within the depth monitored were initially relatively uniform with respect to penetration resistance and therefore had comparable initial conditions.

In order to assess changes in penetration resistance on test plots resulting from biocementation, DCP measurements taken before treatment (day 0 ) and following treatment (day 20) were compared. In addition, measurements taken at times after treatment (day 64 and day 318) were compared with the day 0 and day 20 condition to assess long-term stability. Measurements are shown for day 0, 20, 64 and 318 for all test plots in Figure 6. For ease of comparison between days, interpretations of the lower and upper bound penetration resistance values for day 0 are shown as dashed lines. Measurements do not appear in the upper 5 to $7 \mathrm{~cm}$ of the soil profile for pre-treatment conditions because the selfweight of the DCP was sufficient to free-fall through this surficial soil. As cemented crusts developed on test plots during treatment, however, measurements became obtainable in shallower soils. Improvement resulting from MICP can therefore be inferred from increases in blow counts at similar depths as well as the appearance of measurements at shallower depths. When comparing the measurements from days 0 and 20, TP1 showed a slight reduction in penetration resistance. Although it is possible that this reduction is an artifact of spatial variability, it may also be a response to increased soil moisture as a result of water application. When comparing results for TP2, measurements appear larger at shallower depths following treatment; however, continued improvement at depths greater than approximately $6 \mathrm{~cm}$ was not observed. When comparing results for TP3, measurements larger appear at shallower depths and increases in blow counts occur to a depth of approximately $22 \mathrm{~cm}$. Lastly, when day 0 and

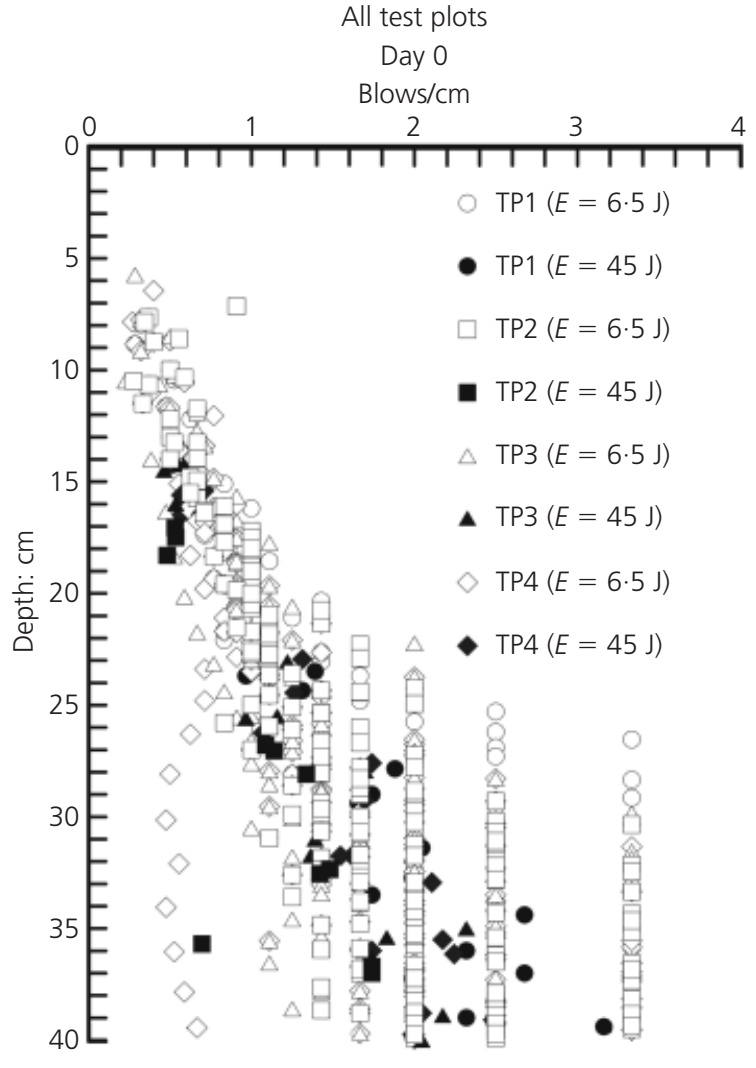

Figure 5. Measurements taken on day 0 using the $45 \mathrm{~J}$ method were shown to be comparable between test plots. Additional measurements taken using the $6.5 \mathrm{~J}$ method were shown to be in agreement with $45 \mathrm{~J}$ measurements

day 20 measurements were compared for TP4, the most significant improvement was observed. Measurements following treatment on TP4 were obtainable at shallow depths near the surface, and increases in blow counts were observed to depths near $30 \mathrm{~cm}$.

Additional DCP measurements were completed $44 \mathrm{~d}$ following final treatment (day 64). Post-treatment measurements (day 64) were compared with final treatment (day 20) measurements to evaluate whether cementation was maintained and assess the possibility that cementation may have continued following final treatment. It is noted that fewer measurement locations were used on day 64 (nine locations) than on day 20 (12 locations). When comparing day 64 to day 20 measurements directly, as expected, TP1 did not show significant changes in penetration resistance. TP2 showed that the lightly cemented crustal improvement shown on day 20 was not maintained on day 64. On TP3 a significant decrease in penetration resistance is apparent at shallow depths on day 64. While this may be due to partial degradation of cementation, the apparent decrease in resistance on day 64 is still within the scatter of day 20 measurements and therefore may be explained by modest spatial variability in improvement. Results for TP4 indicate that the improvement shown on day 20 was largely maintained on day 64 . The results suggest that the 

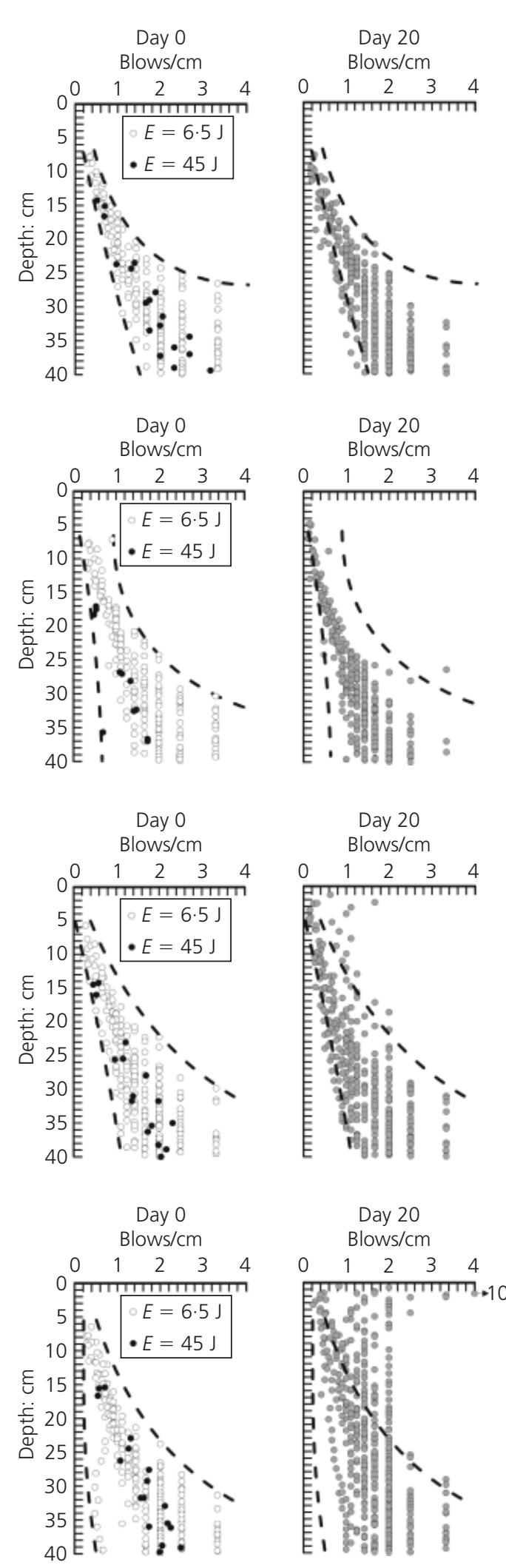

Figure 6. DCP results are shown for each test plot, as measured on days $0,20,64$ and 318. Dashed lines bound all day 0 data to provide reference for assessing changes in penetration resistance.
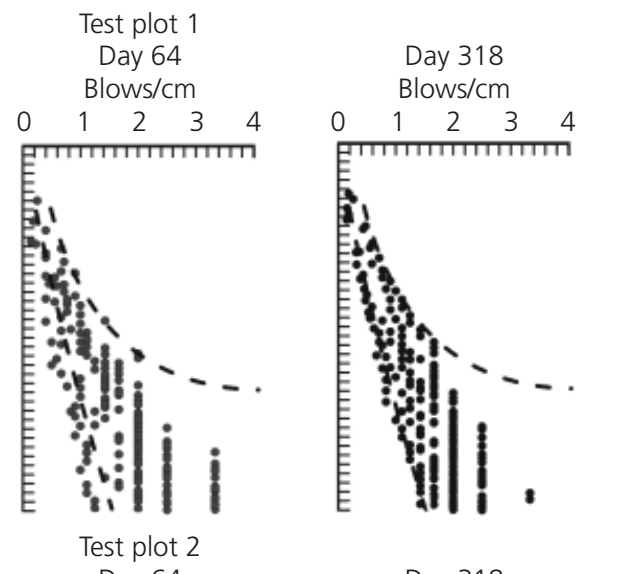

Calcite content: \%

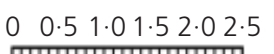

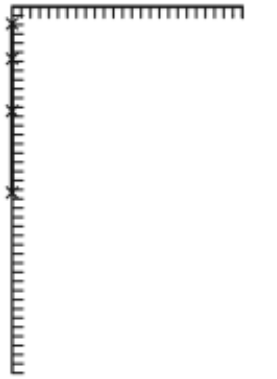

Calcite content: \%

Day 64

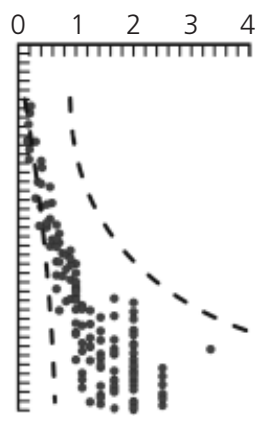

Day 318

Blows $/ \mathrm{cm}$

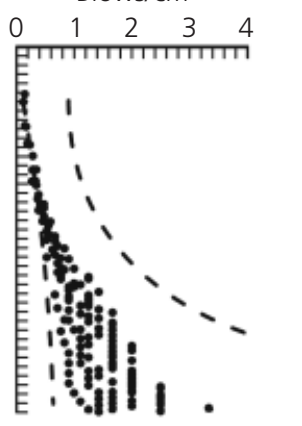

\begin{tabular}{llll}
0 & 0.5 & 1.0 & 1.52 \\
\hline
\end{tabular}

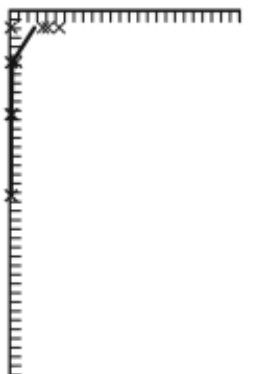

Test plot 3

Day 64

Blows $/ \mathrm{cm}$

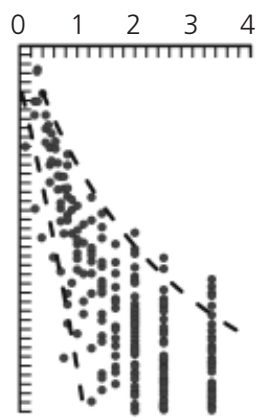

Day 318

Blows $/ \mathrm{cm}$

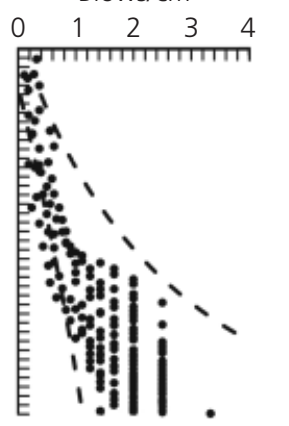

Test plot 4

Day 64

Blows $/ \mathrm{cm}$

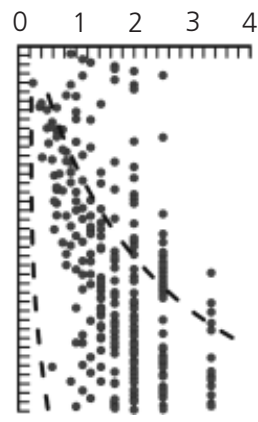

Day 318

Blows $/ \mathrm{cm}$

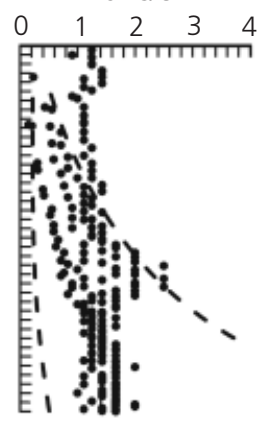

Calcite content: \%
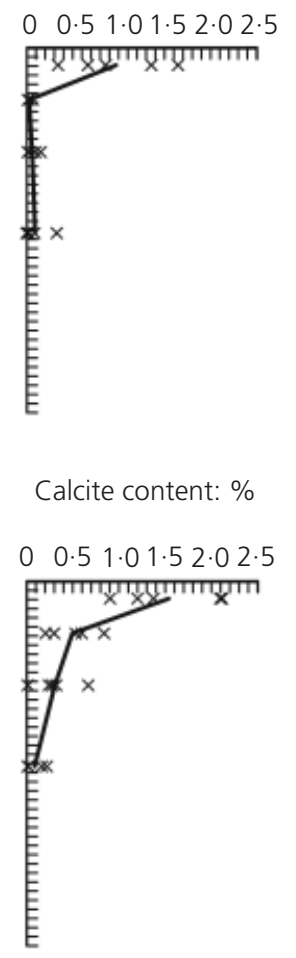

Final calcite content measurements taken on day 20 and averages (solid line) are also shown with depth 
cementation on TP4 did not degrade substantially within $44 \mathrm{~d}$ following final treatment.

In order to assess the ability of the biocementation improvement to persist following a harsh winter season where temperatures dropped as low as $-41{ }^{\circ} \mathrm{C}$, additional DCP measurements were taken $298 \mathrm{~d}$ after treatments were completed (day 318). Day 318 measurements were taken at similar locations as day 64 measurements. Following the winter season substantial amounts of windblown sand covered the test plots. In order to account for the resulting depth offset, wind-blown sands were excavated at measurement locations to determine the depth to the cemented crust. This depth was assumed to be the depth to the plot surface before sand deposition. DCP measurements were then corrected to the appropriate reference elevation assuming this offset. On TP1 and TP2 where cemented crusts were not present, measurements were corrected assuming similar sand deposition on these plots as other plots. When comparing day 318 to day 64 results, TP1 and TP2 both showed no substantial change during this time. Furthermore, TP3 showed no substantial degradation of cementation at the surface; however, it appeared that some degradation may have occurred at depths greater than $15 \mathrm{~cm}$. Lastly, TP4 showed slight degradation of cementation across the measurement depth, yet still exhibited improvement outside the day zero scatter to approximately $17 \mathrm{~cm}$. These results indicate that achieved biocementation may be resistant to harsh winter conditions and degrade moderately $298 \mathrm{~d}$ following final treatment.

Free-fall distances of the DCP instrument were also recorded over time to provide a quantifiable measure of surficial crust development. Figure 7 presents these free-fall distances plotted with time for each test plot. As expected, the $45 \mathrm{~J}$ ( $8 \mathrm{~kg}$ hammer) measurements have slightly larger free-fall distances than $6.5 \mathrm{~J}(4.6 \mathrm{~kg}$ hammer) measurements due to an increase in hammer mass. Interpretation lines show the general trend of $4.6 \mathrm{~kg}$ hammer free-fall distances for each plot. Initial day zero measurements show that all four test plots had similar free-fall distances before treatment. Control TP1 free-fall distances remained reasonably constant throughout the treatment, whereas TP2, TP3 and TP4 had similar trends in increased resistance to free-fall. TP2 showed a reduction in free-fall distance of about $4 \mathrm{~cm}$, and TP3 had a reduction of about $5.5 \mathrm{~cm}$. TP4, however, had the largest reduction in free-fall distance of about $6 \mathrm{~cm}$. Free-fall distances on TP3 and TP4 were shown to be similar because both plots were approaching a state of zero free-fall.

DCP results support the previous qualitative observations and suggest that the TP4 treatment formulation was the most effective. The results for this test plot therefore warranted further analysis. All DCP measurements taken during treatment on TP4 were compared with depth and time. These measurements were stored in five different time intervals for day 0 , days 2 to 6 , days 8 to 12 , days 14 to 18 and day 20, and averaged over $5 \mathrm{~cm}$ intervals. The stored measurements are plotted in Figure 8, and show increases in penetration resistance in time. As shown, the crust formation on TP4 was most prominent beyond day 6 of the overall treatment. An intersection between day 0 and day 20 lines also appears to occur at a depth of approximately $28 \mathrm{~cm}$, indicating that the treatment method resulted in some modest level of improvement near the targeted $30 \mathrm{~cm}$ depth.

\subsection{Calcite content}

Calcite content measurements were performed to determine increases in calcite content following the treatment programme. The final calcite content measurements and their averages (solid line) are shown for all test plots in Figure 6. TP1 showed no change in calcite content with depth or time as expected. TP2 samples had calcite contents up to $0 \cdot 5 \%$ near the ground surface and reduced to $0 \%$ by approximately $5 \mathrm{~cm}$ below the surface. TP3 samples had calcite contents up to $1.6 \%$ near the ground surface and reduced to $0.5 \%$ or less below $5 \mathrm{~cm}$. Lastly, TP4 samples had measurable calcite precipitation over the entire
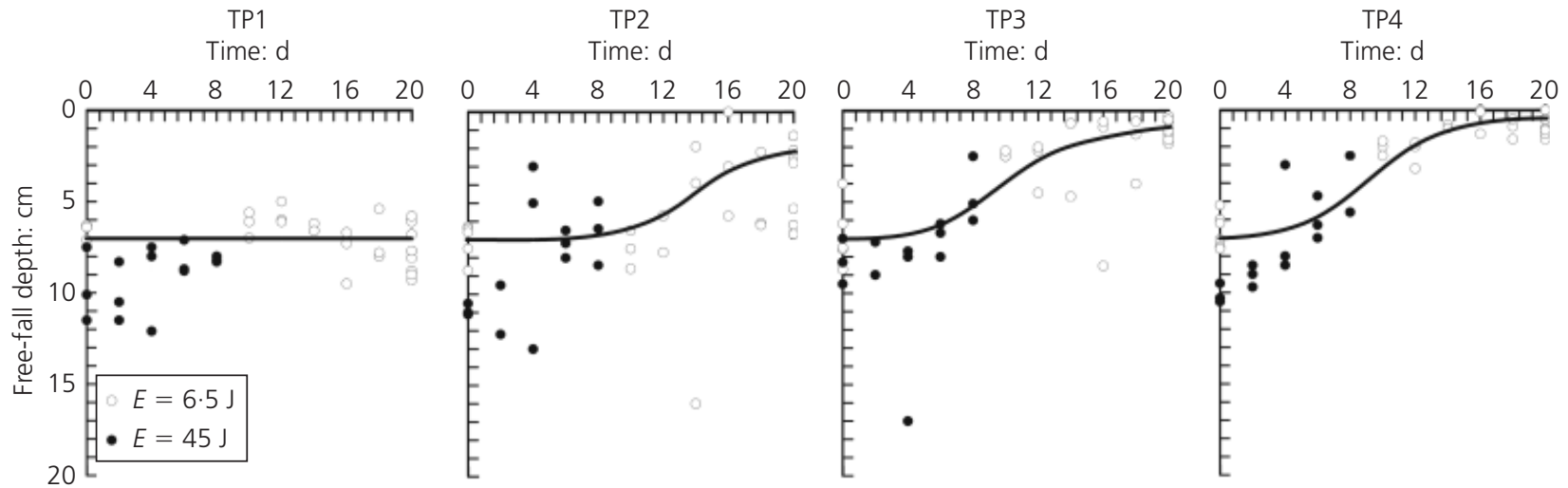

Figure 7. DCP free-fall distances show the progression of free-fall crustal penetration resistance with time. Solid lines are included to represent the interpreted trend in free-fall distances for the lower energy 6.5 J method 


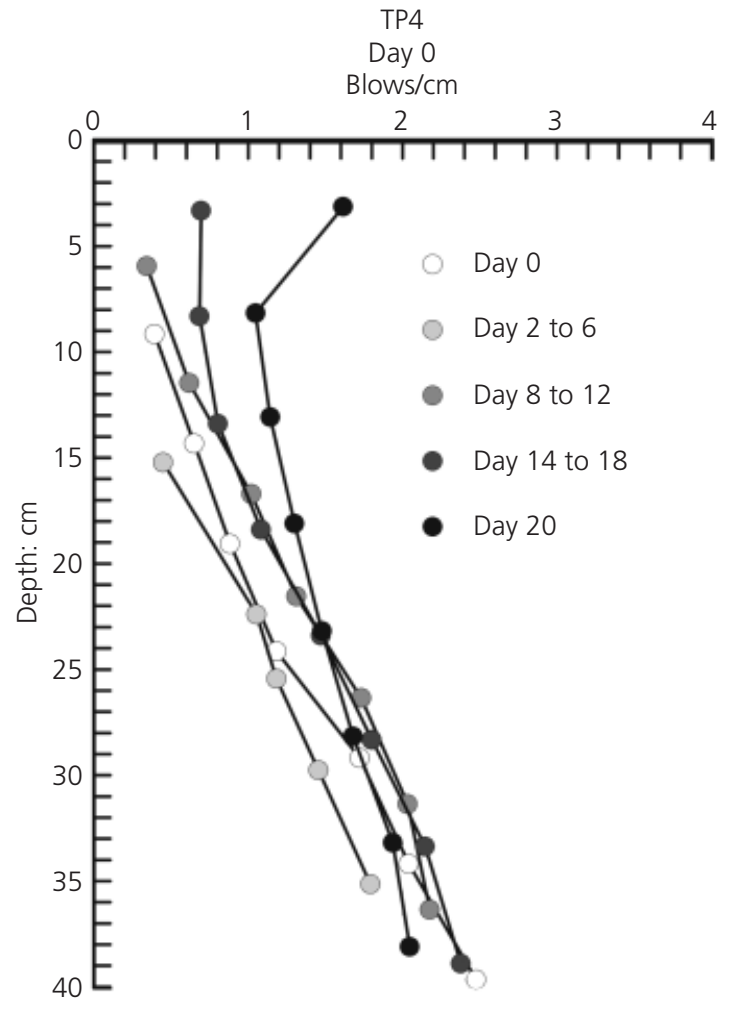

Figure 8. TP4 DCP measurements binned in time intervals and averaged every $5 \mathrm{~cm}$ to show the progression of penetration resistance with time

sampling depth, with calcite contents up to $2 \cdot 1 \%$ near the ground surface and $0.5 \%$ or less below approximately $10 \mathrm{~cm}$. These results suggest that the highest calcite precipitation occurred on TP4. This result is consistent with previous results from the DCP testing programme and from other qualitative measures, which also concluded that improvement on TP4 was the most substantial.

\section{Conclusions}

The results of this study indicate that soils treated with the TP4 formulation were improved to a depth of approximately $28 \mathrm{~cm}$ after $20 \mathrm{~d}$ of treatment. The formation of a cemented crust on all treated plots indicates that soils were improved on these test plots to various degrees. Water jet impingement erosion tests were shown to be effective at assessing improvement qualitatively; however, the development of a quantitative test would be ideal. DCP measurements were shown to be capable of achieving highresolution data with depth when lower energy hammer blows are implemented. Lastly, calcite content measurements were shown to be effective in quantifying calcite precipitation with depth.

Crust thickness measurements, water jet impingement erosion tests, calcite content measurements and DCP data each conclude that the low-concentration treatment solutions applied to TP4 achieved the greatest improvement, whereas the high and medium concentrations on TP2 and TP3, respectively, were not optimal. This test plot was observed to have a stiff competent surface crust that measured up to $2.5 \mathrm{~cm}$, a significant increase in DCP resistance to depths greater than $5 \mathrm{~cm}$, and a measurable calcite content of up to $2 \cdot 1 \%$. Modest spatial variability across TP4 was observed from crust thickness measurements as well as DCP and calcite content measurements taken at similar depths. In addition, improvement throughout the $28 \mathrm{~cm}$ depth on TP4 was observed to have no significant signs of deterioration $44 \mathrm{~d}$ after the final treatment, with only moderate degradation occurring $298 \mathrm{~d}$ after final treatment following a harsh winter. The highest improvement measured on TP4 was unexpected and a definitive explanation for this result has not been confirmed. While several explanations for the lower improvement on TP2 and TP3 were considered, additional tests could not be completed off-site and therefore these hypothesises could not be validated.

Additional field-scale applications will provide further insight with respect to the effect of calcium and urea concentrations on achieved cementation. The success of the low-concentration treatments applied to TP4 suggests that lower quantities of chemical amendments may be needed for future field-scale applications than originally anticipated. The results from this field study are promising and demonstrate the potential of MICP as an effective soil improvement method.

\section{Practical relevance of work}

Microbially induced calcite precipitation is a bio-mediated cementation process that can improve the geotechnical properties of granular soils through the precipitation of calcite at soil particle contacts. Bio-cemented soils have been observed experimentally to exhibit increased soil matrix stiffness, initial shear stiffness and shear strength. Potential engineering applications for MICP bio-cementation include liquefaction mitigation, general ground improvement, contaminant immobilisation, slope stability, concrete damage remediation and erosion prevention. This process has shown great promise at the laboratory scale; however, more recent field applications such as the one presented in this study have demonstrated the potential of this technology for practical field-scale applications.

\section{Acknowledgements}

The authors would like to thank Cameco Corporation for providing a field test site and financial support to perform this MICP pilot study.

\section{REFERENCES}

ASTM (2002) D4373-02: Standard test method for rapid determination of carbonate content of soils. ASTM International, West Conshohocken, PA, USA.

ASTM (2009) D6951-09: Standard test method for use of the dynamic cone penetrometer in shallow pavement applications. ASTM International, West Conshohocken, PA, USA.

Burbank MB, Weaver TJ, Green TL, Williams BC and Crawford RL (2011) Precipitation of calcite by indigenous microorganisms 
to strengthen liquefiable soils. Geomicrobiology Journal 28(4): 301-312.

Chu J, Ivanov V, Lee MF, Oh XM and He J (2009) Soil and waste treatment using biocement. In Proceedings of the International Symposium on Ground Improvement Technologies and Case Histories (Leung CF, Chu J and Shen RF (eds)). Research Publishing Services, Singapore, pp. 165-170.

Chu J, Stabnikov V and Ivanov V (2012) Microbially induced calcium carbonate precipitation on surface or in the bulk of soil. Geomicrobiology Journal 29(6): 544-549.

DeJong JT, Fritzges MB and Nüsslein K (2006) Microbial induced cementation to control sand response to undrained shear. Journal of Geotechnical and Geoenvironmental Engineering, ASCE 132(11): 1381-1392.

DeJong JT, Soga K, Banwart SA et al. (2010) Soil engineering in vivo: harnessing natural biogeochemical systems for sustainable, multi-functioning engineering solutions. Journal of the Royal Society Interface 8(54): 1-15.

Ferris FG, Stehmeier LG, Kantzas A and Mourits FM (1996) Bacteriogenic mineral plugging. Journal of Canadian Petroleum Technology 35(8): 56-61.

Hamdan N, Kavazanjian E, Rittmann BE and Karatas I (2011) Carbonate mineral precipitation for soil improvement through microbial denitrification. In Geo-Frontiers 2011. ASCE, Reston, VA, ASCE Geotechnical Special Publication No. 211, pp. 3925-3934.

Harkes MP, Booster JL, van Paassen LA and van Loosdrecht MCM (2008) Microbial induced carbonate precipitation as ground improvement method - bacterial fixation and empirical correlation $\mathrm{CsCO}_{3}$ vs strength. In Proceedings of the 1st International Conference on Bio-Geo-Civil Engineering, Delft, Netherlands, pp. 37-41.

Martinez BC and DeJong JT (2009) Bio-mediated soil improvement: load transfer mechanisms at the micro- and macro-scales. In US-China Workshop on Ground

Improvement Technologies. ASCE, Reston, VA, ASCE Geotechnical Special Publication No. 188, pp. 242-251.

Montoya BM, Gerhard R, DeJong JD et al. (2012) Fabrication, operation, and health monitoring of bender elements for aggressive environments. ASTM Journal of Geotechnical Testing, ASCE 35(5): 1-15.

Smith RW, Fujita Y, Hubbard SS and Ginn TR (2012) US Department of Energy Final Report Grant No. DE-FG0207ER64404: Field Investigations of Microbially Facilitated Calcite Precipitation for Immobilization of Strontium-90 and other Trace Metals in the Subsurface. US Department of Energy, Washington, DC, pp. 1-20, Technical Report DEO/ ER64404-01.

Stocks-Fisher S, Galinat JK and Bang SS (1999) Microbiological precipitation of $\mathrm{CaCO}_{3}$. Soil Biology and Biochemistry 31(11): 1563-1571.

Tagliaferri F, Waller J, Ando E et al. (2011) Observing strain localization processes in bio-cemented sand using $\mathrm{x}$-ray imaging. Granular Matter 13(3): 247-250.

van Paassen LA (2011) Bio-mediated ground improvement: from laboratory experiment to pilot applications. In Geo-Frontiers 2011. ASCE, Reston, VA, ASCE Geotechnical Special Publication No. 211, pp. 4099-4108.

Weaver T, Burbank M, Lewis R et al. (2011) Bio-induced calcite, iron, and manganese precipitation for geotechnical engineering applications. In Geo-Frontiers 2011. ASCE, Reston, VA, ASCE Geotechnical Special Publication No. 211, pp. 3975-3983.

Whiffin VS, van Paassen LA and Harkes MP (2007) Microbial carbonate precipitation as a soil improvement technique. Geomicrobiology Journal 24(5): 417-423.

\footnotetext{
WHAT DO YOU THINK?

To discuss this paper, please email up to 500 words to the editor at journals@ice.org.uk. Your contribution will be forwarded to the author(s) for a reply and, if considered appropriate by the editorial panel, will be published as a discussion in a future issue of the journal.

Proceedings journals rely entirely on contributions sent in by civil engineering professionals, academics and students. Papers should be 2000-5000 words long (briefing papers should be 1000-2000 words long), with adequate illustrations and references. You can submit your paper online via www.icevirtuallibrary.com/content/journals, where you will also find detailed author guidelines.
} 